\title{
A VERTENTE COMPORTAMENTAL DA EDUCAÇÃO FINANCEIRA
}

\author{
THE BEHAVIORAL STREAM OF FINANCIAL EDUCATION
}

\author{
Celso Ribeiro Campos ${ }^{1}$ \\ Cileda de Queiroz e Silva Coutinho ${ }^{2}$ \\ Auriluci Carvalho de Figueiredo ${ }^{3}$
}

\begin{abstract}
Resumo: A Estratégia Nacional de Educação Financeira foi implantada em 2010, mas não resultou em melhora da situação financeira das famílias. Ao contrário, o consumo das famílias tem aumentado mais do que a renda, provocando mais endividamento e inadimplência (CAMPOS; HESS; SENA, 2018). Em nossas pesquisas sobre educação financeira, temos identificado duas vertentes, instrumental e crítica. A vertente instrumental trata o indivíduo como consumidor de produtos financeiros, enquanto a vertente crítica tem um viés social e humanístico. Apesar de termos defendido a vertente crítica, os resultados não parecem ser suficientes. Com isso, buscamos explorar outra vertente, a comportamental. Neste artigo, apresentamos conceitos básicos de economia e fazemos uma resenha de duas obras de Zygmunt Bauman, para depois explorarmos os conceitos de economia comportamental. Nosso objetivo é trazer essa vertente para o universo da educação financeira, contribuindo para que se possa entender melhor como trabalhar esse tema no âmbito da sala de aula.
\end{abstract}

Palavras-chave: Educação financeira; Economia comportamental; Consumismo; Bauman.

\begin{abstract}
National Strategy for Financial Education was implemented in 2010 but did not result in any improvement in the families' financial situation. On the contrary, household consumption has increased more than income, leading to more indebtedness and defaults (CAMPOS; HESS; SENA, 2018). In our research on financial education we have identified two streams, instrumental and critical. The instrumental stream treats the individual as consumer of financial products, while the critical has a social and humanistic bias. Although we have defended the critical stream, the results do not seem enough. Thus, we seek to explore another stream, the behavioral. In this article, we present basic economics concepts and review two of Zygmunt Bauman's works, and then explore the concepts of behavioral economics. Our goal is to bring this aspect to the financial education universe, helping to better understand how to work on this theme within the classroom.
\end{abstract}

Keywords: Financial education; Behavioral economics; Consumerism; Bauman.

\footnotetext{
${ }^{1}$ Doutor em Educação Matemática pela Universidade Estadual Paulista (UNESP). Professor pesquisador da Pontifícia Universidade Católica de São Paulo (PUC), São Paulo, SP, Brasil. E-mail: crcampos@pucsp.br

${ }^{2}$ Doutora em Didática da Matemática pela Université Joseph Fourier - Grenoble I, França. Professora pesquisadora da Pontifícia Universidade Católica de São Paulo (PUC), São Paulo, SP, Brasil. E-mail: cileda@pucsp.br

${ }^{3}$ Doutora em Educação Matemática pela Pontifícia Universidade Católica de São Paulo (PUC). Professora pesquisadora da Universidade Metropolitana de Santos (UNIMES), Santos, SP, Brasil. E-mail: aurilucy@uol.com.br
} 


\title{
1 Introdução
}

A importância da Educação Financeira (EF) no Brasil é destacada pela Estratégia Nacional de Educação Financeira (ENEF), promovida pelo Banco Central do Brasil, e corroborada na Base Nacional Comum Curricular (BNCC):

Outro aspecto a ser considerado nessa unidade temática é o estudo de conceitos básicos de economia e finanças, visando à educação financeira dos alunos. Assim, podem ser discutidos assuntos como taxas de juros, inflação, aplicações financeiras (rentabilidade e liquidez de um investimento) e impostos. Essa unidade temática favorece um estudo interdisciplinar envolvendo as dimensões culturais, sociais, políticas e psicológicas, além da econômica, sobre as questões do consumo, trabalho e dinheiro (BRASIL, 2018, p. 269).

O texto da BNCC sugere diversos temas relacionados com a EF, entre os quais as aplicações financeiras, mas não há menção a empréstimos, por exemplo. Sugere também estudos interdisciplinares envolvendo, entre outros temas, o consumo, mas não cita o endividamento e o uso de cartões de crédito, entre outros.

Encontramos na BNCC uma menção à EF como fator de inserção crítica e consciente do cidadão (estudante) no mundo:

\begin{abstract}
Há hoje mais espaço para o empreendedorismo individual, em todas as classes sociais, e cresce a importância da educação financeira e da compreensão do sistema monetário contemporâneo nacional e mundial, imprescindíveis para uma inserção crítica e consciente no mundo atual. Diante desse cenário, impõem-se novos desafios às Ciências Humanas, incluindo a compreensão dos impactos das inovações tecnológicas nas relações de produção, trabalho e consumo (BRASIL, 2018, p. 568).
\end{abstract}

Apesar da menção da inserção crítica, o texto sugere a compreensão do sistema monetário contemporâneo nacional e mundial, impactos nas relações de trabalho e consumo, entre outros temas, mas não passa nem perto de citar problemas de superendividamento, inadimplência, a questão das altas taxas de juros etc., que são característicos da realidade brasileira. Diante disso, entendemos que a BNCC, assim como a ENEF (COUTINHO; CAMPOS, 2018), trata a EF preponderantemente sob o viés instrumental, sem tocar nas feridas do sistema financeiro brasileiro, tais como as taxas de juro altíssimas cobradas pelos bancos, a concentração bancária etc. (gráficos 1 e 2 respectivamente) e tampouco sugere abordar as consequências da falta de EF pelas famílias (orçamento familiar, planejamento, consumismo, endividamento). Adicionalmente, vale destacar que a EF presente na BNCC é tratada principalmente como tema transversal no ensino médio, sendo que a Matemática é sugerida para a sua abordagem preponderantemente quando se trabalha o conteúdo de porcentagens no ensino fundamental. 


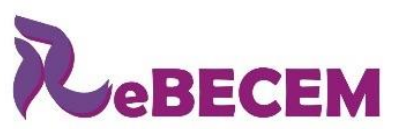

\section{Revista Brasileira de Educação em \\ Ciências e Educação Matemática}

DOI: http://dx.doi.org/10.33238/ReBECEM.2019.v.3.n.2.22614

Gráfico 1: Taxas de juro ao ano por modalidade de crédito - média dos cinco maiores bancos - Brasil

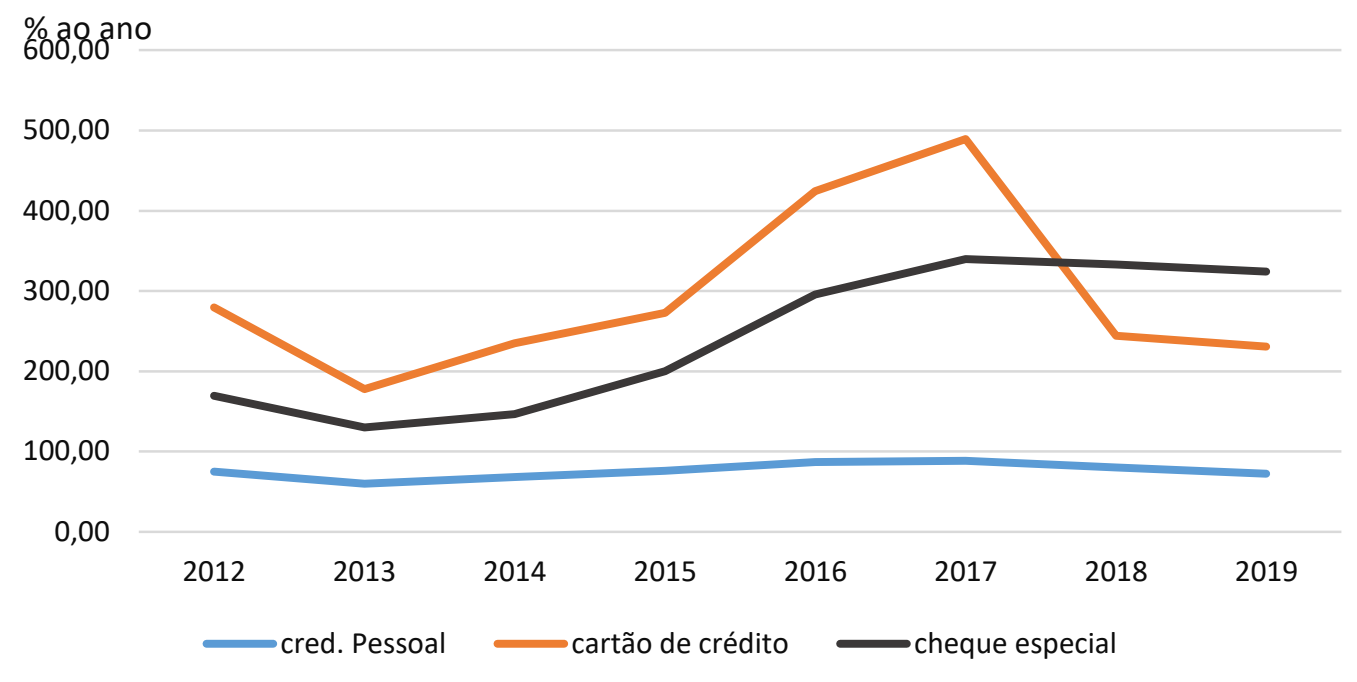

Fonte: Dados de Banco Central do Brasil ${ }^{4}$

Gráfico 2: Ativo total dos maiores bancos do Brasil - 2017 (em \% do total)

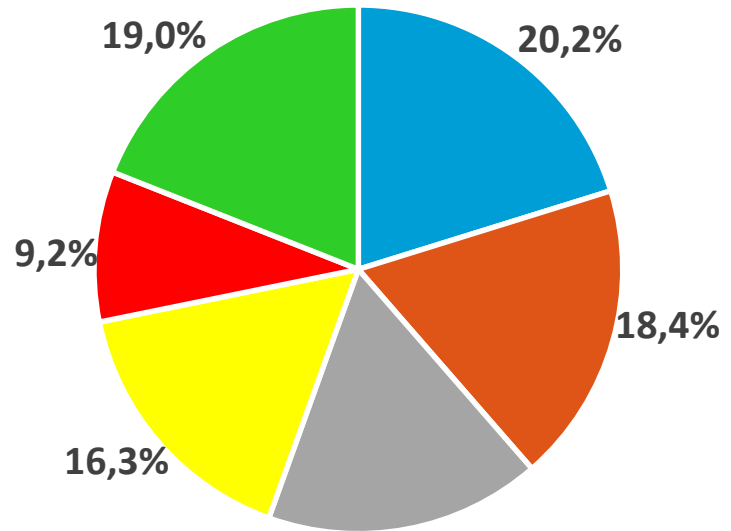

- Itaú

- BB

- Caixa

Bradesco

- Santander

- Outros

\section{$16,9 \%$}

Fonte: Dados de Valor Econômico ${ }^{5}$

Temos defendido a vertente crítica da Educação Financeira (EF) em oposição à vertente instrumental (CAMPOS; COUTINHO, 2019; COUTINHO; CAMPOS, 2018), a qual trata a EF como meio de promover a eficiência do sistema financeiro e os indivíduos como consumidores de produtos financeiros. A vertente crítica por nós defendida tem um viés social, busca uma abordagem humanística e trabalha o fortalecimento de capacidades individuais e o empoderamento individual do cidadão, juntamente com sua emancipação social.

\footnotetext{
${ }^{4}$ https://www.bcb.gov.br/estatisticas/txjuros

${ }^{5}$ https://www.valor.com.br/valor1000/2018/ranking100maioresbancos
} 


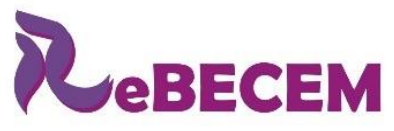

DOI: http://dx.doi.org/10.33238/ReBECEM.2019.v.3.n.2.22614

\section{Revista Brasileira de Educação em \\ Ciências e Educação Matemática}

Outro aspecto importante que não podemos nos furtar a comentar diz respeito ao fraco resultado da $\mathrm{ENEF}^{6}$, tendo em vista o que se refere à importante questão do endividamento das famílias brasileiras (gráfico 3) juntamente com o aumento do consumo em maior proporção do que o aumento da renda (gráfico 4).

Gráfico 3: Percentual de famílias endividadas

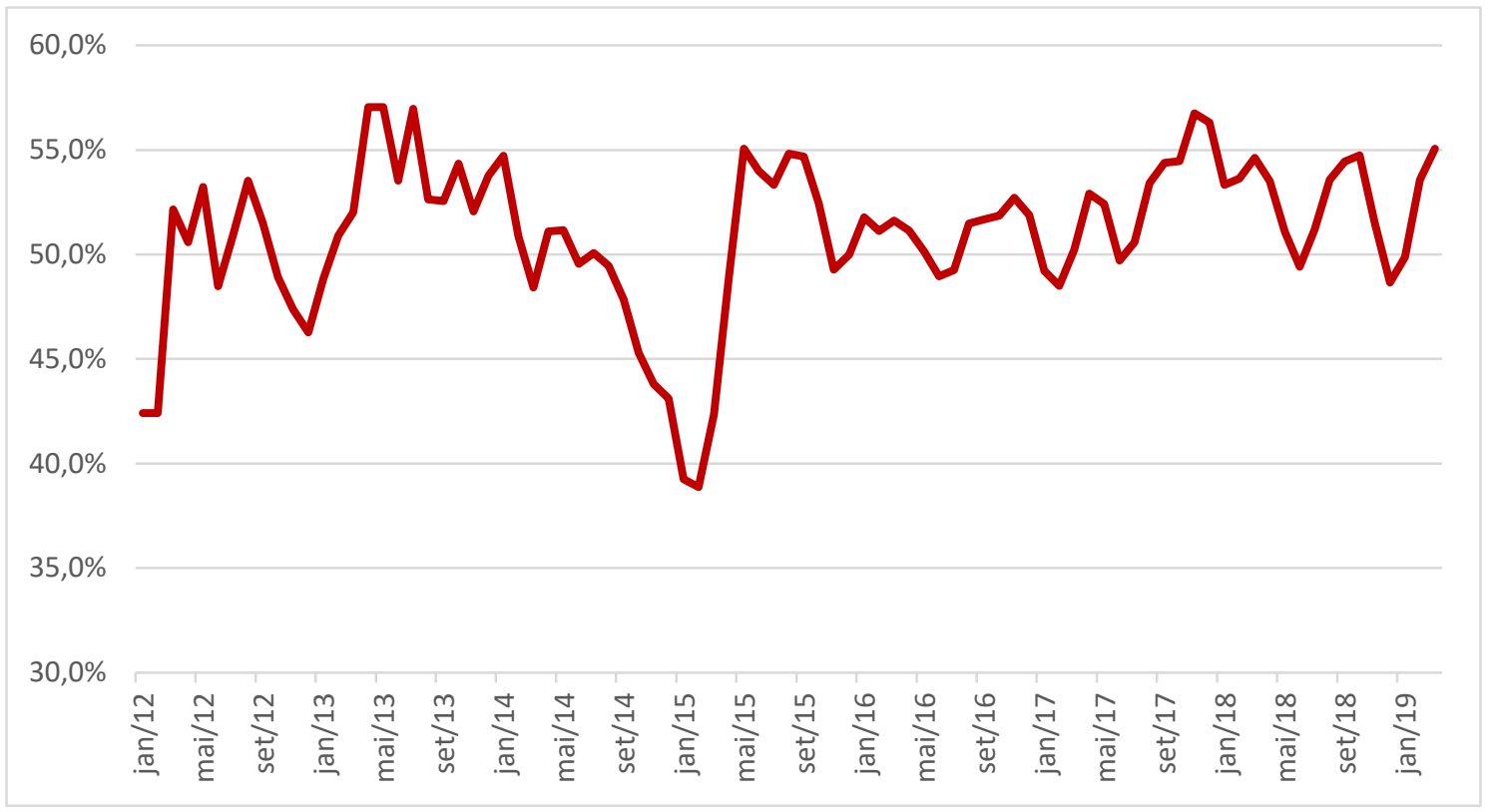

Fonte: Dados de PEIC março/20197

Gráfico 4: Índice de salário mínimo, renda média, PIB per capita e consumo das famílias - Brasil (2002 $=100)$

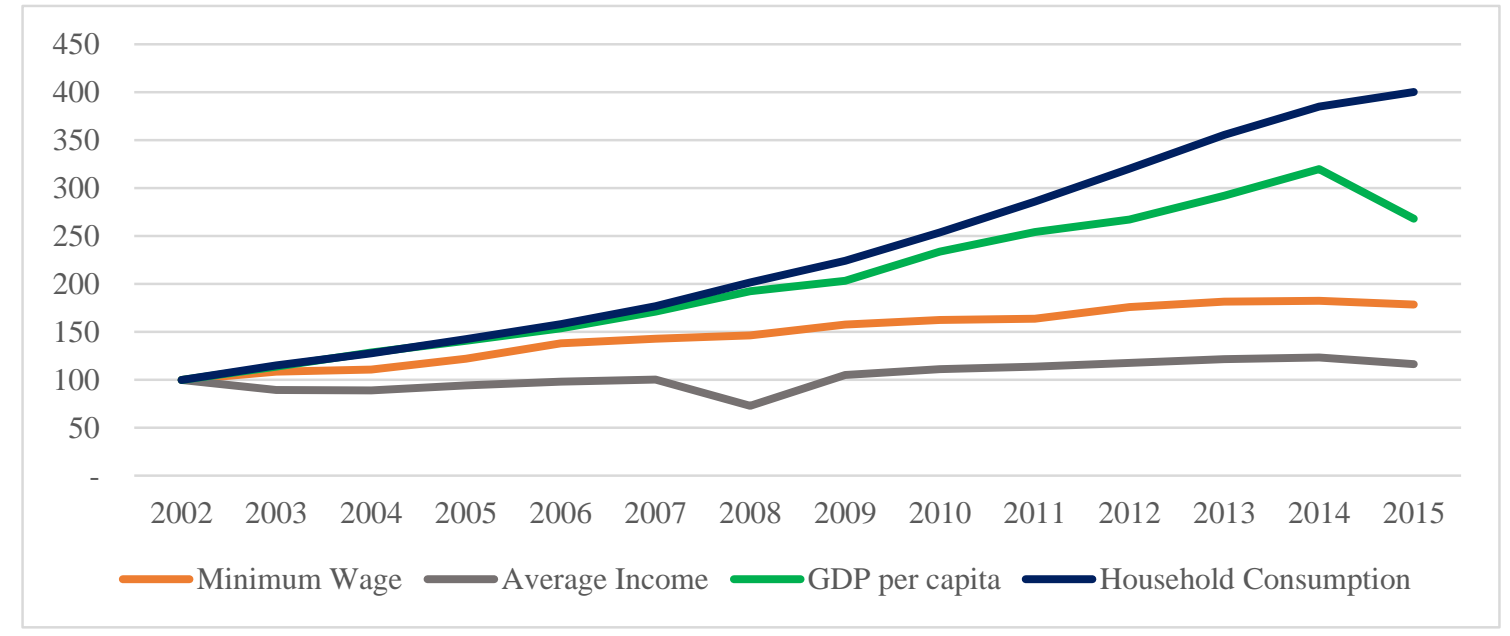

Fonte: Campos, Hess e Sena (2018, p. 119)

Não temos condições de avaliar o quanto a vertente crítica da EF tem contribuído para reverter a problemática evidenciada nos gráficos, mas é possível supor que mesmo

\footnotetext{
${ }^{6}$ Criada por meio do Decreto Federal 7.397/2010

${ }^{7}$ https://www.fecomercio.com.br/pesquisas/indice/peic
} 
DOI: http://dx.doi.org/10.33238/ReBECEM.2019.v.3.n.2.22614

indivíduos informados sobre os principais conceitos de EF ainda tenham dificuldade de coloca-los em prática. Diante dessa hipótese, temos o objetivo de apresentar neste trabalho uma terceira vertente para a EF, qual seja a comportamental. Para mostrar a importância dessa nova vertente, vamos apresentar alguns conceitos básicos de Economia, em seguida, vamos nos debruçar sobre duas obras do sociólogo e filósofo Zygmunt Balman, que são Vida a crédito e Vida para o consumo, depois vamos abordar alguns aspectos da chamada economia comportamental. Nossa intenção é extrair desse estudo os conceitos e/ou aspectos que vão nortear a vertente comportamental da EF.

\section{Alguns princípios básicos de economia}

A economia pode ser dividida em dois ramos principais, a microeconomia e a macroeconomia. A microeconomia "lida com o comportamento de unidades econômicas individuais - consumidores, empresas, trabalhadores e investidores - assim como os mercados que essas unidades englobam” (PINDYCK; RUBINFELD, 2010, p. 4). Já a macroeconomia "lida com as variáveis econômicas agregadas, tais como a taxa de crescimento e nível do produto nacional, taxas de juros, desemprego e inflação" (idem, op. cit., p. 4). Dito isso, vamos focar nossas atenções na microeconomia, que traz alguns princípios que são importantes para entender o fenômeno que desejamos analisar, mas também vamos destacar um aspecto que nos interessa sobre macroeconomia.

a) Os recursos são escassos e a microeconomia estuda como a sociedade administra esses recursos, ou seja, como as pessoas decidem o que comprar, quanto trabalhar, economizar e gastar, assim como as empresas decidem quanto produzir, quantos trabalhadores contratar etc.

b) O tradeoff é um termo que significa escolha conflitante. Como os recursos são escassos, consumidores, trabalhadores e empresas de deparam com tradeoffs o tempo todo, pois todas as decisões envolvem trocas.

Os consumidores têm renda limitada, a qual pode ser gasta em uma ampla
variedade de bens e serviços ou poupada para o futuro. A teoria do consumidor
[...] descreve como os consumidores, com base em suas preferências,
maximizam o próprio bem-estar optando por comprar mais unidades de
determinado bem e, em contrapartida, adquirir menos de outro (PINDYCK;
RUBINFELD, 2010, p. 4).

Certamente você conhece o provérbio: 'nada é de graça'. Ele expressa uma grande verdade. Para conseguirmos algo que queremos, geralmente precisamos abrir mão de outra coisa de que gostamos. A tomada de decisões exige escolher um objetivo em detrimento de outro (MANKIW, 2010, p. 4). 
DOI: http://dx.doi.org/10.33238/ReBECEM.2019.v.3.n.2.22614

c) As pessoas agem de forma racional, mas as opções disponíveis nunca são completamente previsíveis, pois existem mudanças (desvios) marginais, para melhor ou para pior. A expressão mudanças marginais serve para descrever pequenos ajustes incrementais a um plano de ação existente.

Os economistas normalmente presumem que as pessoas são racionais. Uma
pessoa racional faz o melhor para alcançar seus objetivos, sistemática e
objetivamente, conforme as oportunidades disponíveis. [...] Um tomador de
decisões racional executa uma ação se, e somente se, o benefício marginal
ultrapassa o custo marginal (MANKIW, 2010, p. 6-7).

d) $\mathrm{O}$ preço de um bem ou serviço é dado pelo que você desiste para consegui-lo. $\mathrm{O}$ consumidor deve sempre fazer uma comparação entre o valor gasto e o benefício obtido. Quando a pessoa decide financiar um bem, ela precisa saber se terá recursos disponíveis para pagar as prestações mensais. Para comprar alguma coisa, sempre é necessário abrir mão de outra coisa, em geral, dinheiro.

Como as pessoas enfrentam tradeoffs, a tomada de decisões exige comparar os custos e benefícios de possibilidades alternativas de ação. Em muitos casos, contudo, o custo de uma ação não é tão claro quanto pode parecer à primeira vista (MANKIW, 2010, p. 5).

e) As pessoas reagem a incentivos. As pessoas fazem escolhas a todo tempo. Essas escolhas são decididas com base no benefício e no custo, considerando-se também as outras variáveis envolvidas. Incentivos provocam mudanças no processo e têm o poder de modificar a decisão que as pessoas tomam. Optar por fazer compras em um estabeleciomento que dá cupons de descontos em compras futuras é um bom exemplo disso.

Como as pessoas racionais tomam decisões comparando custo e benefício, elas respondem a incentivos, que tem papel importante no estudo de economia. Certo economista sugeriu que todo o setor da economia poderia ser simplesmente resumido com a seguinte frase: 'As pessoas respondem a incentivos. O resto são comentários’ (MANKIW, 2010, p. 7).

f) A satisfação do consumidor. Pindyck e Rubinfeld (2010, p. 62) pontuam que "Diante das preferências e da limitação de renda, os consumidores escolhem comprar as combinações de mercadorias que maximizam sua satisfação. Essas combinações dependerão dos preços dos vários bens disponíveis”. Entretanto, os autores refletem que as decisões dos consumidores nem sempre são racionais:

Sabemos que os consumidores nem sempre tomam decisões de compra racionalmente. Às vezes, por exemplo, eles compram por impulso, ignorando ou não levando em conta suas restrições orçamentárias (e, assim, assumindo dívidas). Outras vezes, os consumidores não têm certeza de suas preferências ou são influenciados pelas decisões de consumo tomadas por amigos ou vizinhos, ou até mesmo por mudanças de humor. Além disso, ainda que os consumidores se comportem racionalmente, nem sempre conseguirão levar em 
DOI: http://dx.doi.org/10.33238/ReBECEM.2019.v.3.n.2.22614

conta, por completo, a multiplicidade de preços e escolhas com que se defrontam diariamente (MANKIW, 2010, p. 62).

Dessa forma, os autores reconhecem que consumidores podem não agir racionalmente. Por conta disso, uma nova área de estudo vem crescendo em importância: a economia comportamental, a qual abordaremos mais adiante.

g) O conceito de utilidade. Uma característica importante da teoria do comportamento do consumidor é o que os economistas chamam de utilidade, um conceito que visa atribuir valores numéricos para os níveis de satisfação das pessoas associados ao consumo.

Na verdade, as pessoas obtêm utilidade apropriando-se de coisas que lhes dão prazer e evitando coisas que lhes trazem insatisfação. Na linguagem da microeconomia, o conceito de utilidade se refere ao valor numérico que representa a satisfação que o consumidor obtém de uma cesta de mercado (PINDYCK; RUBINFELD, 2010, p. 72).

A função de utilidade consiste em uma fórmula que atribui um valor não monetário (chamado nível de utilidade) a cada conjunto de itens consumidos. Uma fórmula comum para esse tipo de função é: $U=Q_{1}$. $Q_{2}$, na qual $Q_{1}$ representa a quantidade consumida do bem 1 e $\mathrm{Q}_{2}$ é a quantidade consumida do bem 2. Nesse exemplo, foram considerados apenas dois bens apenas por motivo de simplificação. $\mathrm{O}$ estudo da utilidade na economia é comumente feito com dois bens para permitir uma representação gráfica no plano cartesiano. Dado um nível de utilidade, ou seja, dado um valor para $U$, a curva resultante da função apresentada é decrescente e recebe o nome de curva de indiferença, pois qualquer ponto da curva confere o mesmo nível de utilidade ao consumidor. Maior utilidade (resultante de maior consumo) resulta em curvas de indiferença mais afastadas da origem, conforme mostra o gráfico 5, que apresenta curvas de indiferença relativas ao consumo de dois tipos de bens, quais sejam alimento e vestuário. Nesse gráfico, $U_{3}>U_{2}$ $>\mathrm{U}_{1}$.

O que determina o nível de utilidade no qual o consumidor se encontra é a restrição orçamentária, ou seja, o dinheiro disponível para consumo. O conceito de utilidade é importante para nós, pois supostamente quantifica a satisfação das pessoas ao consumir, além de deixar claro que quanto maior o consumo, maior será a satisfação. 
DOI: http://dx.doi.org/10.33238/ReBECEM.2019.v.3.n.2.22614

Gráfico 5: Funções de utilidade e curvas de indiferença

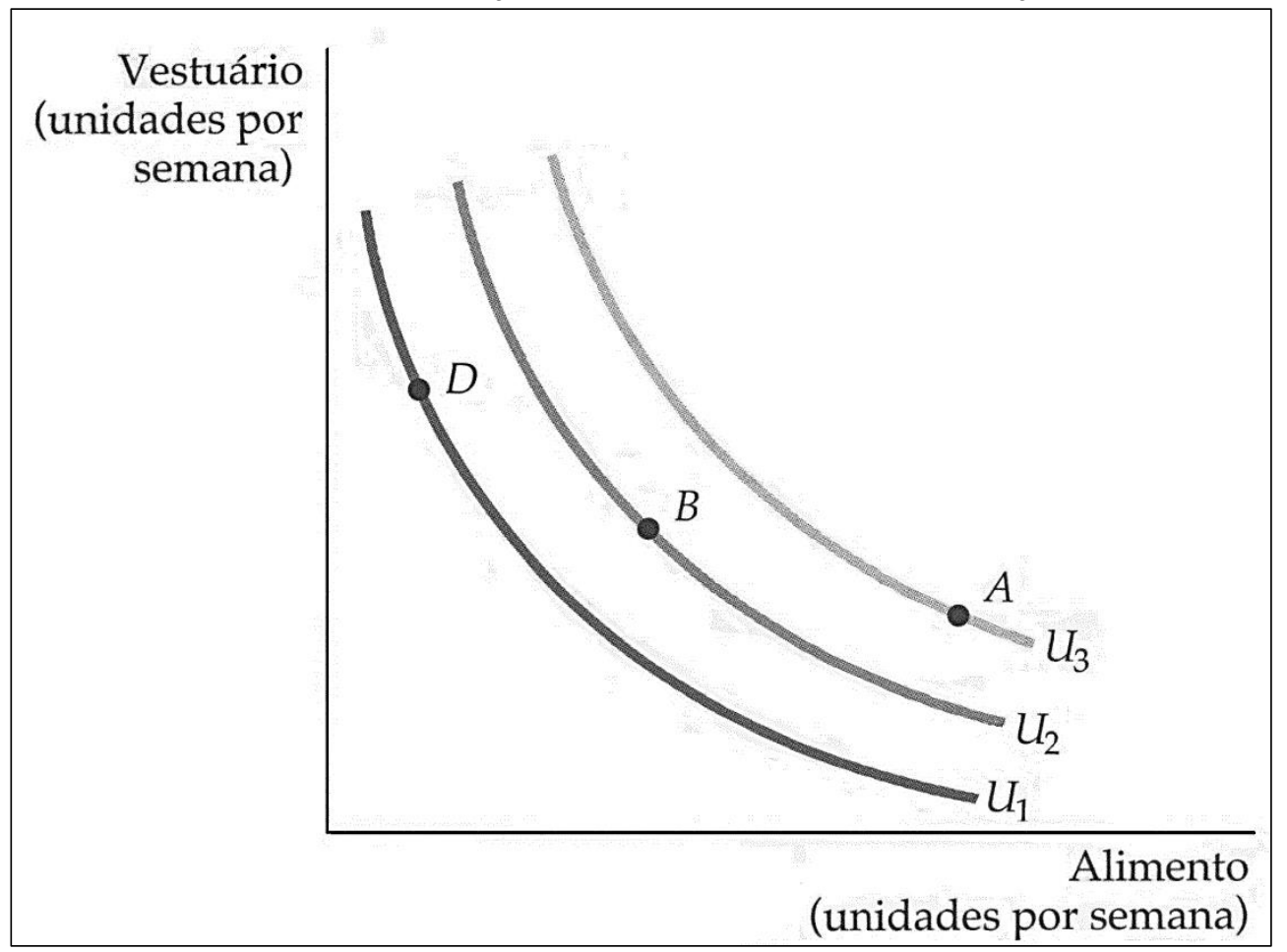

Fonte: Pindyck; Rubinfeld (2010, p. 66)

h) O consumo, a poupança e a renda. Até onde conhecemos, a teoria econômica não faz menção sobre a satisfação em poupar. Contudo, é importante também mencionar uma função básica da macroeconomia que aparece no estudo do equilíbrio da renda nacional. Essa função (que é uma forma simplificada de representação) indica que a renda ( $\mathrm{Y}$, do inglês yeld), é igual ao consumo (C) mais a poupança ( $\mathrm{S}$, do inglês saving), ou seja:

$$
Y=C+S
$$

Com isso, entendemos que só existem duas formas de alocar a renda: poupança ou consumo. Como a poupança não gera satisfação, resta ao cidadão satisfazer-se consumindo!

A função consumo é frequentemente representada por uma função do primeiro grau do tipo:

$$
C=a . Y+b
$$

Nessa expressão, $a$ representa a propensão marginal a consumir, ou seja, o quanto é destinado ao consumo um aumento de $\$ 1$ na renda. Supõe-se que essa propensão marginal a consumir seja positiva e menor que 1 . Sendo positivo o valor de $a$, sabemos que a função consumo é crescente, ou seja, quanto maior a renda, maior o consumo.

A lei psicológica fundamental na qual podemos confiar totalmente, tanto a priori, a partir do nosso conhecimento da natureza humana, como a partir dos 


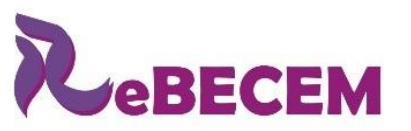

Revista Brasileira de Educação em

Ciências e Educação Matemática

DOI: http://dx.doi.org/10.33238/ReBECEM.2019.v.3.n.2.22614

fatos detalhados da experiência é que os homens tendem, como regra e na média, a aumentar o seu consumo quando a renda aumenta, mas não na mesma proporção da renda (KEYNES,1985, p. 75).

Por um lado, Keynes (op. cit.) afirma ainda que, se a sociedade decidir consumir o total de qualquer incremento da renda (ou seja, $a=1$ ), não haverá um equilíbrio estável. Por outro lado, se a propensão marginal a consumir for maior que 1, está em curso uma situação de endividamento coletivo e não haverá renda para pagar a dívida enquanto essa propensão marginal a consumir não cair abaixo de 1. "O consumo - para repetir o óbvio - é o único fim e objetivo da atividade econômica (idem, op. cit., p. 80). Apenas para completar a análise, esclarecemos que o parâmetro $b$ da função consumo representa o consumo autônomo, que representa um valor mínimo para subsistência, o que é necessário mesmo quando a renda é nula - nesse caso ele provém de poupanças passadas ou pela geração de dívidas.

Esses conceitos de economia serão importantes para entendermos e traduzirmos o comportamento do consumidor, sob a luz da $\mathrm{EF}$, que faremos mais adiante.

\section{A vida de consumo e crédito descrita e analisada por Zygmunt Bauman}

Bauman (1925-2017) nasceu na Polônia, sofreu com a perseguição nazista durante a Segunda Guerra Mundial e refugiou-se na então União Soviética, para tempos depois emigrar para Londres. O sociólogo e filósofo polonês construiu uma sólida reputação internacional, exercendo influência em todas as áreas das ciências humanas. Bauman (2001) criou o conceito de modernidade líquida, segundo a qual os indivíduos estão sempre correndo sobre um gelo fino sem saber o motivo pelo qual correm, mas sabendo que se pararem afundarão e morrerão na existência pós-moderna. Em outras palavras, se não aderirmos à velocidade do mundo atual, seremos engolidos por sua essência, deixados para trás. Nesse contexto, o autor indaga: Corremos para onde?

Neste estudo, focaremos nossa atenção em duas obras específicas desse autor: "Vida para consumo" e "Vida a crédito". Nossa ideia é buscar nessas obras um entendimento da realidade do mercado consumidor sob o ponto de vista da sociologia. Para tanto, faremos uma resenha, capítulo por capítulo, dos dois livros mencionados, buscando extrair alguns conteúdos importantes para nossa análise de EF. 


\subsection{Vida para consumo - a transformação das pessoas em mercadoria (BAUMAN, 2008)}

\section{a) Introdução}

Pessoas que não têm dinheiro nem cartões de crédito e que não demonstram empolgação por compras e se mostram imunes aos apelos do marketing tendem a ser rejeitadas automaticamente. Para ser aceito no jogo do consumo, é preciso ser um jogador rico e ávido.

Bauman lista três regras que seriam designadas para o mercado de trabalho, mas que segundo ele seriam válidas para quaisquer mercados:

- o destino de toda mercadoria disponível para venda é ser comprada por consumidores;

- os consumidores irão comprar as mercadorias somente se eles acreditarem que elas irão satisfazer seus desejos;

- o preço que o consumidor está disposto a pagar pelas mercadorias depende intensidade dos seus desejos e da credibilidade das promessas de satisfação desses desejos.

Essa terceira regra se aproxima bastante do que foi descrito na alínea (d) do item anterior, sobre os conceitos de economia.

Assim, "os encontros dos potenciais consumidores com os potenciais objetos de consumo tendem a se tornar as principais unidades na rede peculiar de interações humanas conhecida, de maneira abreviada, como sociedade de consumidores" (BAUMAN, 2008, p. 19). Esta se diferencia por uma reconstrução das relações humanas com base nas relações entre os consumidores e os produtos de consumo.

O retrato dos consumidores vai desde o que representa um pateta ou bobalhão cultural até o que se reconhece como herói da modernidade, na medida em que eles são ludibriados pelas promessas enganosas e seduzidos pelas manobras poderosas do marketing.

O autor conta um caso de uma professora de escola básica que pergunta aos alunos o que eles querem ser quando crescer, e ela ouve a resposta: ser famoso. Segundo o autor, isso significa aparecer nas primeiras páginas, ser notado, desejado e comentado. Embora ele reconheça que há muito mais coisas na vida além exposição na mídia, o autor observa que não há muito, pois nesta era da informação, o anonimato representa a morte. 
DOI: http://dx.doi.org/10.33238/ReBECEM.2019.v.3.n.2.22614

Ainda sobre a sociedade dos consumidores, Bauman (2008) aponta que para alguém se tornar sujeito, é preciso primeiro transformar-se em uma mercadoria desejada e desejável.

Sobre as redes sociais ${ }^{8}$ e os encontros pela internet, o autor cita que

Isso reflete uma mudança fundamental na forma como as pessoas são estimuladas a pensar sobre seus relacionamentos pessoais e organizar suas vidas, com a intimidade apresentada em público e sujeita a normas contratuais que se poderia associar à compra de um carro, uma casa ou uma viagem de férias (BRISTOW ${ }^{9}$, sd apud BAUMAN, 2008, p. 24).

A atração exercida por essas redes sociais deriva da exposição das pessoas como mercadorias, do mesmo tipo com que os consumidores comuns estão acostumados. Usar a internet para escolher um parceiro é um processo que apresenta as mesmas características de se fazer compras online. Nesse processo se escolha, uma novidade tentadora é seguida de outra, de tal forma que a felicidade está nas compras, ao passo que a aquisição em si, com possibilidade de gerar efeitos colaterais incômodos ou inconvenientes, representa uma grande probabilidade de frustação, dor ou remorso. A sociedade dos consumidores se baseia, em última instância, em uma ilusão, uma mentira.

A curta expectativa de vida de um produto é superada com a chegada de novas ofertas, acompanhadas de um processo de difamação das anteriores. A insatisfação dos consumidores é enfrentada com o descarte das coisas que a provocam. Dessa forma, a indústria de remoção de lixo é fundamental para a sociedade dos consumidores.

Embora reconheça que nenhuma caracterização singular do consumo e do consumidor seja suficiente, o autor propõe o que ele chama de três tipos ideais: o consumismo, a sociedade dos consumidores e a cultura consumista, os quais ele se propõe a investigar e descrever.

\section{b) Consumismo versus consumo}

O consumo é uma atividade diária comum, rotineira, sem muito planejamento nem reconsiderações. O consumo é um ato perene e impossível de ser removido, pois é essencial para a sobrevivência, com raízes antigas.

Apesar de a atividade de consumir deixar pouco espaço para a inventividade, isso não é aplicável ao papel desempenhado pelo consumismo na atual dinâmica do jeito humano de ser e estar no mundo.

\footnotetext{
8 'Redes sociais' é uma tradução nossa para o termo 'internet agencies' usado pelo autor.

9 Jennie Bristow, "Shopping for love", em www.spiked-online.
} 
A passagem do consumo ao consumismo representa uma revolução, quando o primeiro se tornou central para a vida da maioria das pessoas, um verdadeiro propósito de existência, quando a capacidade de querer, desejar, experimentar a emoção de consumir muitas vezes passou, de fato, a servir de referência para o convívio humano.

O consumismo é um tipo de arranjo social resultante da reciclagem de vontades, desejos e anseios humanos rotineiros, permanentes e, por assim dizer, neutros quanto ao regime, transformando-os na principal força propulsora e operativa da sociedade, uma força que coordena a reprodução sistêmica, a integração e a estratificação sociais, além da formação de indivíduos humanos, desempenhando ao mesmo tempo um papel importante nos processos de auto identificação individual e de grupo, assim como na seleção e execução de políticas de vida individuais (BAUMAN, 2008, p. 41).

O consumismo não associa a felicidade à mera satisfação de necessidades, mas sim a uma crescente intensidade de desejos, que por sua vez requer o uso imediato e a rápida substituição dos objetos adquiridos. Ele congrega a insaciabilidade dos desejos juntamente com a urgência de sempre procurar as mercadorias necessárias para ele se locupletar. Novas necessidades vão surgir, exigindo novas mercadorias, que por sua vez vão criar outras necessidades e desejos, alimentando uma obsolescência que já vem embutida nos bens disponíveis no mercado.

Segundo o autor, um ambiente líquido moderno é hostil ao planejamento e ao investimento de longo prazos - a maioria dos bens perde seu brilho e sua atração rapidamente. Na vida agorista das pessoas dessa era consumista, a pressa se justifica pelo impulso de comprar e abandonar ou substituir. Quando a satisfação gerada pelos objetos dos desejos de ontem deixam se completa, eles devem ser descartados.

A economia consumista é alimentada pela circulação das mercadorias e é considerada pujante quanto mais o dinheiro muda de mãos. Isso acontecendo, muitos produtos de consumo estarão a caminho do lixo. Na sociedade de consumidores, a busca pela felicidade é o mote mais usado como isca nas campanhas de marketing destinadas a reforçar a disposição dos consumidores para gastarem seu dinheiro.

A economia consumista baseia-se no excesso e no desperdício para atender as necessidades, impulsos e compulsões. Na economia consumista, a regra é que os produtos aparecem primeiro para só depois aparecer a sua utilidade.

A ideia mais típica da sociedade de consumidores é uma vida feliz, por isso ela promete a felicidade instantânea no aqui e agora e a cada agora sucessivo. Contudo, a capacidade do consumo para aumentar a felicidade é decrescente e não pode ser estendida de forma ilimitada. Não existe qualquer evidência de que, com o crescimento do consumo, o número de pessoas que afirmam serem felizes também vá aumentar. $\mathrm{Na}$ 
DOI: http://dx.doi.org/10.33238/ReBECEM.2019.v.3.n.2.22614

verdade, a sociedade de consumo prosperará, segundo o autor, enquanto tornar perpétua a não satisfação das pessoas. A demanda por consumo se esgotaria sem a repetida frustração dos desejos, e a economia voltada para o consumidor ficaria sem fôlego.

O consumismo é também uma economia do engano, pois é fincado na irracionalidade dos consumidores e não em suas estimativas racionais e bem informadas, valoriza as emoções consumistas e não dá espaço para o raciocínio lógico. Nesse contexto, o consumidor líquido-moderno sempre precisa de mais, pois ele nunca tem o bastante.

\section{c) Sociedade de consumidores}

A sociedade de consumidores estimula a opção por um estilo de vida e uma razão existencial consumistas, rejeitando as outras opções culturais. Nela a adaptação aos mandamentos de uma cultura de consumo é a única escolha aprovada de maneira plena. Numa sociedade de consumidores, todos precisam ser consumidores por vocação.

O pobre é forçado a uma situação na qual tem de gastar o pouco dinheiro ou os parcos recursos de que dispõe com objetos de consumo sem sentido, e não com suas necessidades básicas, para evitar a total humilhação social e evitar a perspectiva de ser provocado e ridicularizado (BAUMAN, 2008, p. 74).

Consumir significa trabalhar para a aceitação social de si mesmo, o que pode ser traduzido em vendabilidade: ter qualidades para as quais já exite demanda de mercado ou repaginar as que já se possui, transformando-as em novas mercadorias para as quais a demanda continua sendo criada.

O objetivo decisivo do consumo na sociedade de consumidores não é a satisfação de necessidades, mas a comodificação do indivíduo, isto é, elevar à categoria de mercadorias vendáveis a condição dos consumidores. Os membros da sociedade de consumidores devem ser eles próprios mercadorias, e é essa qualidade que os torna autêncos dessa sociedade.

A passagem de um mundo de restrições de liberdade para outro de autonomia e autodomínio é retratada como o trunfo final do direito do indivíduo à autoafirmação, a soberania do sujeito livre de responsabilidades em uma sociedade que tem como premissa o direito à livre escolha. Assim, o membro da sociedade de consumidores é, acima de tudo, segundo Bauman (2008), um Homo eligens.

Os indivíduos que fracassam na competência de consumir são considerados consumidores falhos, categorizados como subclasse, com acesso recusado a todas as 


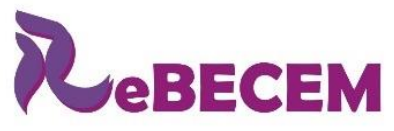

DOI: http://dx.doi.org/10.33238/ReBECEM.2019.v.3.n.2.22614
Revista Brasileira de Educação em

Ciências e Educação Matemática

classes sociais reconhecidas, inaceitáveis como membros da sociedade, quase sempre figurando nas estatísticas como pobres ou pessoas abaixo da linha de pobreza.

A participação ativa nos mercados de consumo é a principal virtude que se cobra dos membros da sociedade de consumidores, afinal quando o crescimento do PIB ameaça diminuir, é dos consumidores procurando gastar, devidamente estimulados, que se espera que coloquem a economia em marcha de avanço, a fim de evitar a recessão.

Segundo Bauman (2008), uma pesquisa realizada pelo Financial Services Authority e a Universidade de Bristol constatou que a geração entre 18 e 40 anos não é capaz de administrar suas dívidas ou acumular um mínimo de poupança: apenas $30 \%$ dos indivíduos dessa geração conseguem guardar dinheiro para compras futuras, enquanto $42 \%$ nada fazem para garantir alguma perspectiva de pensão. Além disso, a pesquisa aponta que $24 \%$ dos jovens estão com suas contas bancárias no negativo.

\section{d) Cultura consumista}

Consumidores plenos aceitam a vida curta das coisas, de certa forma com um prazer disfarçado, sem remorso por destinarem algo para o lixo. O valor de cada objeto está tanto em suas virtudes como em suas limitações. Uma sociedade de consumo é uma sociedade de excesso e de desperdício.

O crescimento econômico é impulsionado pela energia e atividade dos consumidores. O ciclo econômico que verdadeiramente mantém a economia em movimento expansionista, é o ciclo do compre, use e descarte.

Para um tipo de sociedade que afirma que a satisfação do indivíduo é seu único motivo e seu maior propósito, um consumidor satisfeito é a ameaça mais apavorante. A satisfação deve ser uma experiência momentânea, a satisfação duradoura deve parecer aos consumidores como uma perspectiva nada agradável, catastrófica. A cultura do consumo atrelou a satisfação à estagnação econômica, por isso as necessidades não podem ter fim, elas devem ser insaciáveis. Somos impulsionados ao mesmo tempo a procurar incessantemente por satisfação, e a temer o tipo de satisfação que nos faria barrar essa procura.

Os pesadelos que assombram o Homo consumens são coisas que ameaçam ficar por mais tempo do que deveriam, produzindo o tédio.

Não é a criação de novas necessidades que caracteriza a sociedade de consumidores, é o desprezo pelas necessidades de ontem e a ridicularização de seus 
DOI: http://dx.doi.org/10.33238/ReBECEM.2019.v.3.n.2.22614

objetos ultrapassados. Pessoas que se satisfazem com um conjunto finito de necessidades, são considerados consumidores falhos, uma variedade de proscritos característica da sociedade de consumidores.

A cultura consumista é marcada por uma pressão crescente para que sejamos alguém mais. A sociedade se concentra na desvalorização imediata de suas antigas ofertas, com o propósito de limpar a área das demandas públicas para que novas ofertas se instalem.

Um mostruário cheio de roupas luxuosas e cercado por multidões à procura de seus 'eus'... Pode-se trocar de roupa sem parar. Assim, como é maravilhosa a liberdade de que usufruem os envolvidos nessa busca... Vamos continuar procurando nossos verdadeiros 'eus', é incrivelmente divertido - sob a condição de que o eu verdadeiro jamais será encontrado. Porque se fosse, a diversão chegaria ao fim... (BAUMAN, 2008, p. 145).

\section{e) Efeitos colaterais do consumismo}

Os efeitos colaterais provocados pelo consumismo se espalham por todo o espectro social, mas existe, contudo, uma nova categoria de indivíduos que podem ser vistos como vítimas do consumismo: a categoria chamada de subclasse.

O termo subclasse implica em uma sociedade que é tudo menos hospitaleira e atenciosa com todos. Subclasse remete à ideia de um conjunto de pessoas que foram declaradas fora dos limites em relação a todas as classes e à própria hierarquia de classes, com poucas ou nenhuma chance de readmissão. São pessoas sem um propósito, que não contribuem de forma útil aos demais, que não constituem uma classe própria, mas se alimentam das essências vitais de todas as classes (como os judeus para os nazistas).

Em uma sociedade de consumidores, a qual avalia qualquer pessoa e qualquer coisa pelo seu valor como mercadoria, a subclasse é formada por indivíduos sem valor de mercado, homens e mulheres não comodificados, e seu fracasso em obter o status de mercadoria autêntica está atrelado ao seu insucesso em se capacitar para uma atividade de consumo plenamente desenvolvida. São consumidores falhos, símbolos dos desastres que aguardam os consumidores decadentes e de qualquer um que deixe de cumprir seus deveres de consumo. Já que são inúteis, os perigos que pressagiam e representam dominam a maneira como são percebidos. Todos os demais integrantes da sociedade de consumidores iriam ganhar se eles desaparecessem.

Bauman aponta que ser da subclasse é diferente de estar na pobreza, pois cair na subclasse seria uma questão de escolha, direta no caso de um desafio aberto às normas sociais, ou indireta se derivada da desatenção às normas ou de não obedece-las com zelo. 


\subsection{Vida a crédito - conversas com Citlali Rovirosa-Madrazo (BAUMAN, 2010)}

\section{a) Introdução}

O livro analisa, de maneira contextualizada historicamente, o significado da primeira crise financeira global do século XXI, estabelecendo relações e indagando suas causas, implicações e alguns dos desafios morais e políticos que emergiram.

A crise financeira global de 2008 e a inabilidade ou relutância dos governos em regular os setores financeiro e bancário - traço característico do que Bauman chama de tempos líquidos -, disparou uma grande recessão que atingiu todo o mundo.

\section{b) Conversa 1: A crise do crédito - resultado do fracasso dos bancos, ou fruto de seu extraordinário sucesso? O capitalismo não está morto}

A criação do cartão de crédito é baseada na filosofia: 'não adie a realização do seu desejo'. Com isso, possibilitou a inversão da ordem dos fatores: desfrute agora e pague depois! As pessoas com o cartão de crédito ficam livres para administrar sua satisfação, para obter coisas quando desejar. Mas cedo ou tarde os empréstimos terão de ser pagos e o adiamento da satisfação é substituído por um adiamento da punição. Ao fim a única coisa que podemos adiar é o momento em que nos daremos conta dessa triste verdade.

Como solução para esses problemas, os bancos oferecem aos clientes mais créditos para pagar as velhas dívidas e ainda para sobrar algum dinheiro extra para novas alegrias. Os bancos tornaram os juros das dívidas a sua principal fonte de lucro. Clientes que pagam seus empréstimos em dia são um pesadelo para os bancos. Quem quiser quitar inteiramente seus débitos antes do prazo deve pagar pesados encargos.

Os clientes que têm uma caderneta de poupança e nenhum cartão de crédito são vistos como um desafio para o marketing, 'terras virgens' clamando uma exploração lucrativa.

Todos que podiam se transformar em devedores e milhões de outros que não podiam e não deviam ser induzidos a pedir empréstimos foram fisgados e seduzidos para fazer dívidas.

$\mathrm{O}$ adestramento para a arte de viver em dívida e de forma permanente foi incluído nos currículos escolares na medida em que os estudantes norte-americanos foram 
DOI: http://dx.doi.org/10.33238/ReBECEM.2019.v.3.n.2.22614

obrigados/encorajados a viver a crédito, a gastar um dinheiro que, na melhor das hipóteses, só ganhariam muitos anos mais tarde.

Como poucas drogas, viver a crédito cria dependência: cultivou-se um hábito, que agora já está bastante arraigado, que é o de correr para os empréstimos cada vez que temos um problema a resolver ou uma dificuldade a superar.

\title{
c) Conversa 2: O Estado de bem-estar na era da globalização econômica
}

Os indivíduos estão cada vez mais abandonados a seus próprios recursos. Esperase que eles divisem soluções individuais para problemas socialmente produzidos, e que o façam de modo específico, usando suas próprias habilidades e recursos particulares. Essas expectativas colocam os indivíduos em concorrência mútua.

Cada indivíduo, seja homem ou mulher, adulto ou criança, rico ou pobre, é convidado (ou levado) a comparar sua própria sorte individual à de outros indivíduos, em particular ao consumo esbanjador das celebridades, e a medir os valores que fazem a vida valer a pena pela opulência que tão ostensivamente eles agitam diante dos outros.

\section{d) Conversa 3: Uma coisa chamada "Estado" - Democracia, soberania e direitos}

\section{humanos}

Bauman cita Giroux:

\begin{abstract}
Sob o reinado do fundamentalismo do livre mercado, as relações comerciais ao mesmo tempo ampliaram seu controle sobre o espaço público e cada vez mais definiram as pessoas como sujeitos consumidores ou como mercadorias, limitando de modo efetivo suas oportunidades de aprender a desenvolver sua gama de capacidades intelectuais e emocionais para se tornarem cidadãos críticos (GIROUX ${ }^{10}, 2009$, apud BAUMAN, 2010, p. 46).
\end{abstract}

Os governos democraticamente eleitos muito têm feito, nas últimas décadas, para transformar o cidadão em um consumidor de serviços oferecidos pelo Estado, e o cidadão ideal, em cliente satisfeito e não queixoso.

A maioria de nós, segundo Bauman, da base ao topo da pirâmide social, hoje teme a ameaça, embora vaga, de ser excluído, de se provar inadequado para os desafios, de ser desprezado, de ter sua dignidade negada e humilhada.

\section{e) Conversa 4: Modernidade, pós-modernidade e genocídio}

10 Bauman não cita a obra, apenas indica que o texto está disponível em: www.counterpunch.org/giroux02062009.html 
A estratégia mais empregada e mais intensamente desejada em nossa era de modernidade líquida é evitar a possibilidade de que qualquer solução se torne definitiva. A ideia de perfeição relativa a um estado em que nenhuma outra alteração é desejável ou bem-vinda, que costumava orientar as mentes criativas e as ações resolutas, agora quase parou de inflamar a imaginação humana. "A partir de uma perspectiva sedutora e de uma condição invejável, o estado de não mais mudar se transformou no fio de que são tecidos os pesadelos e as distopias (BAUMAN, 2010, p. 82).

\section{f) Conversa 5: População, produção e reprodução de refugos humanos}

Em Vidas desperdiçadas escrevi: “Sempre há um número demasiado deles.
'Eles' são os sujeitos dos quais deveria haver menos - ou, ainda melhor, não
deveria haver nenhum. E nunca há um número suficiente de nós. 'Nós' são as
pessoas das quais deveria haver mais" (BAUMAN, 2010, p. 89, aspas do
autor).

Em uma sociedade de consumidores, há os consumidores falhos, ou seja, pessoas carentes de recursos para adicionar à capacidade do mercado de consumo, criando outro tipo de exigência à qual a indústria orientada pelo consumo não pode responder e não pode lucrar. Os consumidores são os principais recursos de uma sociedade de consumo, os consumidores falhos são seus passivos mais fatigantes e dispendiosos.

\section{Conversa 6: Fundamentalismo secular versus fundamentalismo religioso - A corrida dos dogmas ou a batalha pelo poder no século XXI}

O cuidado de si, a busca dos próprios interesses e a felicidade são os principais deveres e obrigações de todos os seres humanos (de fato, o propósito da vida), as exigências éticas precisam se justificar em termos dos benefícios que a obediência a elas possa trazer para o bem-estar e o autodesenvolvimento do obediente.

Sei que tirar vantagem é errado, e sei que estou tirando vantagem, mas essa é a maneira como as coisas são, assim é a realidade. Sabe-se que a vida, e cada escolha, é uma farsa, mas esse conhecimento tornou-se tão universalmente aceito que já não existe qualquer alternativa. Todo mundo sabe que todo mundo tira vantagem, então todo mundo faz isso, e, se eu não fizesse, no final pagaria por ser honesto (GROSSBERG, 2007 apud BAUMAN, 2010, p. 104).

Conversa 7: A escrita do DNA - Uma nova gramatologia para uma nova economia. Dos homines mortales aos pós-humanos FVM no advento da genetocracia 
DOI: http://dx.doi.org/10.33238/ReBECEM.2019.v.3.n.2.22614

A genômica e a engenharia genética podem ser vistas como o maior sonho do homo consumens, como o rompimento da última fronteira no percurso do consumidor moderno, o derradeiro estágio de uma longa e tortuosa luta que chega ao final vitoriosa, para expandir a liberdade dos consumidores, a luta para sua coroação.

As mulheres em um estado não aperfeiçoado oferecem inúmeras possibilidades de aprimoramento. A poderosa empresa farmacêutica Allergan (a mesma introduziu o Botox) anunciou que os cílios fracos e finos poderiam ser corrigidos por uma loção chamada Latisse. Essa loção faria as pestanas brotarem, e até os cílios mais imperceptíveis crescerem e ficarem mais visíveis. Isso, porém, com a condição de que ela fosse usada regularmente, dia após dia - para sempre. Se você interrompesse a terapia contínua, seus cílios retornariam à abominável condição prévia.

As tentações são muitas, há uma resposta para cada preocupação, de modo que quase toda mulher pode encontrar pelo menos um desejo a ser atendido.

\begin{abstract}
Se você sentir que seus seios são muito pequenos e exigem um aumento, ou se você quiser redescobrir o corpo que tinha antes de dar à luz os seus filhos, com uma lipoaspiração ou abdominoplastia, podemos ajudá-la a encontrar o procedimento adequado para você. Os efeitos do envelhecimento podem ser revertidos, e os traços que lhe incomodaram durante anos podem ser remodelados, conquistando-se um novo físico que não poderia ser alcançado com exercícios nem uma dieta saudável (BAUMAN, 2010, p. 111 ${ }^{11}$ ).
\end{abstract}

Nenhuma parte do corpo de uma mulher deve ser vista como algo inatingível para os aperfeiçoamentos. A insegurança é um capital potencial que nunca seria deixado ocioso por qualquer empresário digno desse nome. Fazer-se à medida de seus sonhos, fazer-se segundo sua própria ordem: é isso, afinal, o que você sempre quis, só faltavam os meios de tornar seus sonhos realidade. Agora os meios estão ao seu alcance. Agora, de novo, você pode subtrair o esperar e assumir o controle de seu próprio ser.

\title{
Conversa 8: Utopia, amor, ou a geração perdida
}

Obter sexo é hoje como pedir uma pizza. Agora é possível encomendar genitália online. Flertar ou seduzir não são mais atos oferecidos voluntariamente, nem considerados necessários ou desejáveis. Algo foi perdido, mas ainda assim, ouvem-se muitos homens e mulheres dizendo que aquilo que se ganhou vale o sacrifício. O que se ganhou foi a conveniência, a redução do esforço e a velocidade, encurtando-se o tempo entre desejo e satisfação.

\footnotetext{
${ }^{11}$ Bauman destaca esse trecho como um anúncio típico de uma clínica de cirurgia plástica.
} 
DOI: http://dx.doi.org/10.33238/ReBECEM.2019.v.3.n.2.22614

Ligações estabelecidas com a ajuda da internet tendem a ser mais fracas e mais superficiais do que as laboriosamente construídas na realidade off-line. Por isso, elas são menos satisfatórias e menos cobiçadas. Mais pessoas agora podem fazer sexo e com maior frequência, porém, em paralelo ao crescimento desses números, tem lugar a elevação do número de pessoas que vivem sozinhas e desenvolvem um doloroso sentimento de abandono. A eles é oferecida a promessa de conseguir o que querem na próxima tentativa, com o fornecimento de mais sexo on-line, apenas para perceber que, longe de satisfazer sua fome de companhia humana, esse alimento em particular, preparado e servido pela internet, apenas torna a privação ainda mais evidente, ao fazer com que se sintam ainda mais humilhados e solitários.

\title{
4 A economia comportamental
}

Segundo Ávila e Inchausti (2017, p. 20) “a economia comportamental é uma área interdisciplinar que tem como objetivo estudar como os fatores emocionais, sociais, psicológicos, cognitivos e econômicos afetam a tomada de decisão dos indivíduos". Os autores pontuam que

\begin{abstract}
A Economia Comportamental é um campo de pesquisas relativamente recente, proveniente da incorporação, pela economia, de desenvolvimentos teóricos e descobertas empíricas no campo da psicologia. A esses se somaram, mais recentemente, as contribuições da neurociência e de outras ciências humanas e sociais. Parte-se de uma crítica à abordagem econômica tradicional, apoiada na concepção do "homo economicus", que é descrito como um tomador de decisão racional, ponderado, centrado no interesse pessoal e com capacidade ilimitada de processar informações. Essa abordagem tradicional, que hoje tende a persistir apenas como padrão normativo, considera que o mercado ou o próprio processo de convergência ao equilíbrio são capazes de solucionar erros de decisão decorrentes de uma racionalidade limitada (ÁVILA; BIANCHI, 2015, p. 14).
\end{abstract}

A economia comportamental (EC) trata de diversas questões relacionadas à tomada de decisões dos indivíduos, tais como a decisão de investir em um produto A ou B tendo em vista os riscos associados, a decisão de comprar ou alugar um imóvel, de fazer um plano de previdência privada ou não, de comprar ou vender ações etc. Nos interessa observar alguns aspectos da EC que tangenciam o nosso objeto de pesquisa, qual seja a educação financeira, no que se refere aos temas relacionados a importantes problemas que afetam nossa sociedade e que aqui identificamos como sendo o consumismo e o endividamento das famílias. Dessa forma, buscamos investigar literaturas relacionadas à EC que possam trazer alguma contribuição para o entendimento da problemática deste trabalho de pesquisa. 
DOI: http://dx.doi.org/10.33238/ReBECEM.2019.v.3.n.2.22614

Franceschini e Hunziker (2011) abordam mostram como o tema do consumo está

ligado à EC:

Dentre os temas mais explorados em Economia Comportamental está o comportamento de consumir, que tem atraído grande número de estudiosos de diversas formações e gerado uma literatura tão vasta a ponto de alguns cientistas advogarem que esta área de pesquisas deveria se tornar uma disciplina autônoma (Abdel-Ghany, 2001; Calder \& Tybout, 1987; Holbrook, 1987). Nesta área de pesquisas, o comportamento de consumir tem sido tratado a partir de uma definição ampla, como qualquer classe de comportamento envolvida na compra, uso e/ou descarte de bens (Calder \& Tybout, 1987; Holbrook, 1987). Contribuições oferecidas por analistas do comportamento têm se concentrado em torno de dois temas gerais: marketing social e comportamentos de escolhas (Oliveira-Castro \& Foxall, 2005). Estudos sobre marketing social tipicamente empregam observações de campo com sujeitos humanos e buscam desenvolver estratégias para modificação de comportamentos humanos in situ (FRANCESCHINI; HUNZIKER, 2011, p. $30)$.

O quadro 1 apresenta algumas descobertas da EC acerca de certos vieses comportamentais que podem interferir e prejudicar a saúde financeira das pessoas.

Quadro 1: Influências que interferem nas decisões das pessoas

\begin{tabular}{|c|l|}
\hline Normas sociais & $\begin{array}{l}\text { As escolhas sofrem influências de normas sociais e do comportamento } \\
\text { dos outros }\end{array}$ \\
\hline Framing & A forma com que uma escolha se apresenta afeta a decisão \\
\hline Status quo & Tendência em permanecer no que é conhecido, na opção padrão \\
\hline Priming & Influência provocada por informações inconscientes ou irrelevantes \\
\hline Âncoras & $\begin{array}{l}\text { Decisões são baseadas em um ponto de referência, que pode ser } \\
\text { consciente ou inconsciente }\end{array}$ \\
\hline Desconto interpessoal & $\begin{array}{l}\text { Decisões são afetadas pelo horizonte de tempo e quando seremos } \\
\text { impactados pela ação }\end{array}$ \\
\hline Falácia do planejamento & Prazos e custos são subestimados quando se planeja uma ação \\
\hline Contexto & O contexto em que vivemos influenciar nossas decisões \\
\hline
\end{tabular}

Fonte: Adaptado de Ávila e Inchausti (2017, p. 20)

O Homo economicus, como descrito pela teoria econômica tradicional, toma decisões racionais e tem preferências estáveis ao longo do tempo, mas Ávila e Inchausti (op. cit.) confrontam as características desse ser com a realidade, representada pelos autores como o Homo sapiens, conforme descrito no quadro 2.

Quadro 2: Características do Homo economicus versus Homo sapiens

\begin{tabular}{|c|c|}
\hline Homo economicus & Homo sapiens \\
\hline São egoístas e lutam pelo próprio bem-estar & Podem ter atitudes altruístas \\
\hline $\begin{array}{l}\text { Maximizam a utilidade escolhendo aquilo que é } \\
\text { melhor, dadas as possibilidades }\end{array}$ & $\begin{array}{l}\text { Não necessariamente fazem as escolhas mais } \\
\text { benéficas quanto aos resultados esperados }\end{array}$ \\
\hline $\begin{array}{l}\text { Processam de maneira ótima todas as informações } \\
\text { possíveis }\end{array}$ & $\begin{array}{l}\text { Suas escolhas são afetadas por diversas } \\
\text { informações, incluindo as irrelevantes }\end{array}$ \\
\hline $\begin{array}{l}\text { A forma que as escolhas são apresentadas não } \\
\text { provocam confusão. }\end{array}$ & $\begin{array}{l}\text { São influenciados pela forma na qual as questões } \\
\text { são apresentadas }\end{array}$ \\
\hline
\end{tabular}


DOI: http://dx.doi.org/10.33238/ReBECEM.2019.v.3.n.2.22614

Não tem problema de autocontrole

O poder de ação é afetado por vieses cognitivos e comportamentais

Fonte: Adaptado de Ávila e Inchausti (2017, p. 21)

Seguindo na busca de explicações para o comportamento do Homo sapiens, não adequado ao padrão previsto pelo Homo economicus, os autores descrevem a teoria do sistema dual, a qual afirma que todos nós tempos duas formas distintas de pensar, as quais são definidas como sistema 1 e sistema 2 (figura 1).

Figura 1: Esquema da teoria do sistema dual
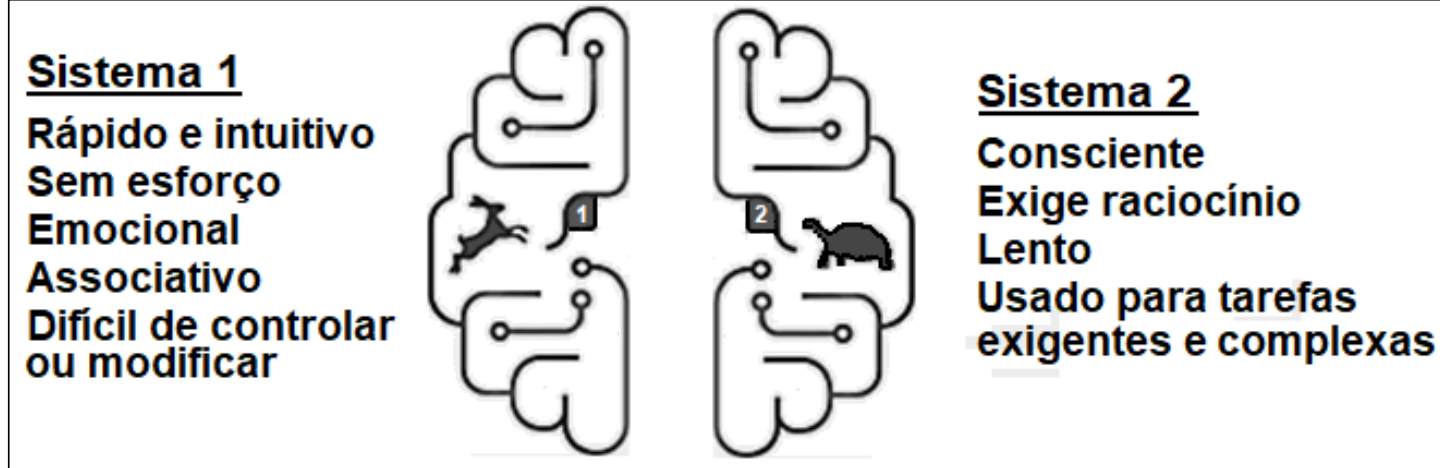

Fonte: Adaptado de Ávila e Inchausti (2017, p. 23)

Enquanto o sistema 1 é simples e involuntário, o sistema 2 é detalhista, complexo e demanda concentração. Assim, eles sugerem que o processo decisório das pessoas segue a lei do menor esforço: o sistema 1, que não pode ser desligado, propõe decisões ao sistema 2, que é mais preguiçoso, por isso ele poupa tempo e responde $o k$ ao sistema 1, e assim fazemos nossas escolhas.

Os erros provocados por decisões tomadas dessa forma serão sistêmicos se não tivermos o poder de controlar esses sistemas e impor um processo, ou seja, mudar o comportamento na medida em que reconhecemos as falhas.

A mitologia grega tem um grande exemplo de como isso acontece. O herói Ulisses, depois de ter vencido a guerra de Troia, passa por inúmeras provações, uma delas é a sua passagem pela Ilha das Sereias. Sabendo que seria tentado pelo belo canto das ninfas, Ulisses tampou os ouvidos de seus homens e ordenou-lhes que o amarrassem ao mastro impedindo que ele cedesse e acabasse jogando-se ao mar. Seduzido pelas sereias ele implorou que o soltassem, mas sua tripulação não podia ouvir. O que salva Ulisses não é sua capacidade de resistir à tentação, mas a consciência de que falharia (ÁVILA; INCHAUSTI, 2017, p. 23).

Segundo os autores, indivíduos sofisticados são os que possuem maior consciência das tentações e falhas de autocontrole. Quanto aos outros indivíduos que não projetam suas tentações nem desenvolvem ações de conscientização, seriam o que eles 
DOI: http://dx.doi.org/10.33238/ReBECEM.2019.v.3.n.2.22614

chamam de Homo behavioralis. O problema do autocontrole é abordado por Pereira et al., (2018), que o relaciona à pobreza:

\begin{abstract}
A escassez de autocontrole pode ser definida como a falta de força de vontade, ou a incapacidade de executar planos previamente estabelecidos. Essa é uma tarefa de difícil esforço, assim como a de regular os próprios pensamentos e emoções (KAHNEMAN, 2016). De acordo com Delaney e Lades (2015), a falha do autocontrole tende a ocorrer quando a tentação domina a capacidade do indivíduo de resistir. Para Datta e Mullunaithan (2014) o autocontrole é um recurso escasso e, portanto, apresenta estoque limitado, de modo que o seu uso em uma tarefa diminui o seu valor disponível para outras atividades. Dessa forma, acredita-se que a pobreza esgota o autocontrole de maneira mais rápida, pois os pobres estão frequentemente sujeitos a mais tentações (BANERJEE; DUFLO, 2012) (PEREIRA et al., 2018, p. 7).
\end{abstract}

Como se vê, os autores tendem a defender a ideia de que a pobreza causa a perda de autocontrole e não vice-versa. Já sobre as tentações de consumo, Franceschini e Hunziker (2011) mencionam um postulado econômico que versa sobre os desejos das pessoas e que se alinha bem com as ideias de Bauman (2008, 2010):

\begin{abstract}
Um exemplo de postulado econômico tomado como "óbvio" nas principais teorias econômicas clássicas seria a de que seres humanos apresentariam "desejos insaciáveis", o que pode ser descrito em linguagem comportamental pela afirmação de que estamos constantemente submetidos a diversas e generalizadas privações de estímulos, seja de líquidos, alimentos, conforto, afetos, status, dinheiro, etc. Apesar de estímulos particulares se tornarem mais ou menos reforçadores ao longo do tempo, não haveria nenhum momento de nossas vidas em que estaríamos plenamente saciados de todos os reforçadores existentes (FRANCESCHINI; HUNZIKER, 2011, p. 31).
\end{abstract}

Embora essas ideias reforcem o pensamento de Bauman (2008 e 2010), as autoras focam seu trabalho mais na questão das escolhas dos consumidores tendo a renda como fator limitante, sem discutir, por exemplo, a questão do endividamento.

É importante também destacar que a ideia de que o homem tem dificuldade em agir racionalmente não é aplicável somente à economia ou às finanças. Ariely (2015) sugere uma série de perguntas para as pessoas refletirem, tais como: nos últimos 30 dias, quantas vezes você comeu demais, teclou no celular enquanto dirigia, gastou tempo demais nas redes sociais, procrastinou, foi deitar muito tarde e não dormiu o suficiente, não se exercitou tanto quanto deveria etc. Essas questões mostram que, se as pessoas não agem racionalmente na sua vida privada comum, por que agiriam racionalmente nas suas finanças?

\title{
5 Voltando à Educação Financeira
}

Os temas aqui tratados se entrelaçam e se complementam, deixando uma série de questionamentos para discussão e reflexão. 
DOI: http://dx.doi.org/10.33238/ReBECEM.2019.v.3.n.2.22614

Da exposição da realidade que fizemos na introdução, podemos questionar a eficácia da ENEF em termos de resultados práticos.

Da BNCC podemos questionar o tipo de abordagem de EF que se espera obter ao classifica-la como tema transversal no ensino médio.

Das vertentes de pesquisa em EF que temos trabalhado (instrumental e crítica), podemos questionar se são abrangentes o suficiente para analisar e explicar os problemas observados relativos às finanças pessoais dos cidadãos.

Da economia, destacamos diversos princípios importantes que nos ajudam a entender essa ciência, mas que nos remetem a um tipo de comportamento padrão, racional, o qual parece se opor ao que se observa na realidade do dia-a-dia do cidadão comum.

De Bauman, aprendemos que a modernidade líquida leva à exacerbação do consumismo, leva à constituição de uma sociedade de consumo e, mais que isso, a uma transformação do cidadão em mercadoria (comodificação). Lendo Bauman, começamos a entender o nosso comportamento errático em relação ao consumo, em relação aos incentivos que recebemos (e aqui vemos uma convergência com um princípio da economia - as pessoas reagem a incentivos) e aos quais respondemos sem refletir sobre suas causas e consequências. Por meio das ideias de Bauman, podemos ao menos entender a nossa pressa, a nossa busca incessante por satisfação, por aceitação e por inserção como membros legítimos de uma sociedade que despreza os consumidores falhos, os quais são rebaixados a uma subclasse.

Já a economia comportamental (EC) acrescenta mais um elo nessa corrente, confrontando o comportamento do cidadão comum com o padrão racional preconizado pela teoria econômica. Mais que isso, a EC procura dar uma explicação lógica para um comportamento ilógico e nessa explicação pode estar o motivo do fracasso da ENEF e da EF como a conhecemos. Percebemos que a EC corrobora o pensamento de Bauman, reforça-o com contornos próprios e, mais do que a reflexão sociológica e filosófica, busca dar uma direção e um sentido para se compreender a realidade. Todas as influências destacadas no quadro 1 estão em concordância com o pensamento de Bauman. Já no quadro 2, percebemos quais são os vieses que influenciam as pessoas e, finalmente, na figura 1 podemos entender o porquê tomamos decisões de forma não racional.

Diante do exposto, entendemos que não é possível obter êxito em uma missão de levar a EF às pessoas de forma efetiva, ou seja, que as coloque no caminho certo da organização de suas finanças pessoais, sem levar em conta uma vertente comportamental, 
DOI: http://dx.doi.org/10.33238/ReBECEM.2019.v.3.n.2.22614

sem discutir os contornos emocionais e cognitivos que levam as pessoas a tomarem decisões erráticas, ilógicas.

\section{Considerações finais}

Ao longo deste texto, levantamos diversos questionamentos para justificar a necessidade da inserção de uma vertente comportamental ao trabalho com EF. Ao alinhavarmos os contornos finais desta investigação, uma questão maior pede reflexão: Como inserir esa vertente comportamental à EF?

Antes de propor uma resposta, é bom reforçar que até este estudo, vínhamos trabalhando em pesquisas envolvendo o letramento financeiro, que envolve duas vertentes que já apresentamos aqui, quais sejam a instrumental e a crítica.

A vertente instrumental tem sido alvo de nossas críticas (CAMPOS; COUTINHO, 2019; COUTINHO; CAMPOS, 2018) na medida em que trata o cidadão como consumidor de produtos financeiros. Não obstante esse viés seja deplorável, tendo em vista a realidade brasileira que apresentamos na introdução deste trabalho, a vertente instrumental tem seu valor ao apresentar a necessidade de conhecimentos de matemática financeira, que formam a base para o entendimento dos problemas reais vivenciados pelos cidadãos, ainda que essa vertente não esteja engajada em expor esse tipo de problema.

Antagonicamente, a vertente crítica valoriza problemáticas relacionadas à realidade dos problemas financeiros das famílias brasileiras, prioriza a reflexão e o debate sobre aspectos fundamentais, tais como as altas taxas de juros, o consumismo (como descrito por Bauman), o uso indevido dos cartões de crédito (também discutido por Bauman), o endividamento e a inadimplência. Contudo, agora podemos perceber que essa vertente trata as questões financeiras de forma ingênua, pois entende que a causa dos problemas discutidos é a falta de informação, a falta de consciência.

A vertente comportamental que ora propomos vem para suprir o que não é explicado com as duas outras vertentes, vem para esclarecer o porquê das decisões não racionais e dos comportamentos ilógicos. Vem para expor a realidade líquida da sociedade de consumo, para escancarar o viés cognitivo e emocional presente na vida cotidiana das decisões erráticas. A consciência da realidade externa proposta pela vertente crítica é agora complementada por uma outra consciência, que é a interna, a consciência de que tomamos decisões com base em nossas emoções, em nossas experiências, considerando todas as influências descritas no quadro 1. Mais ainda, a vertente 


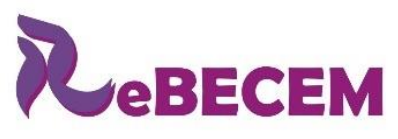

Revista Brasileira de Educação em
Ciências e Educação Matemática

DOI: http://dx.doi.org/10.33238/ReBECEM.2019.v.3.n.2.22614

comportamental mostra os perigos de deixar o Sistema 1 preponderar nas decisões, em detrimento do Sistema 2, conforme mostramos na figura 1, mas alerta para o fato de que a falta de autocontrole e de força de vontade é provocada por uma escassez desses recursos, cujo estoque é limitado - fato que impacta em maior intensidade as pessoas economicamente mais vulneráveis (PEREIRA et al., 2018).

Dito isso, voltemos à pergunta principal que queremos responder: Como inserir a vertente comportamental no âmbito da EF?

Para responder a esse questionamento, vamos recorrer a um exemplo prático. Como estamos falando de decisões erráticas e ilógicas, vamos pensar em: 1) Por que as pessoas comem junkfood se sabem que isso faz mal à saúde? 2) Por que fumam se sabem que isso traz consequências ruins e irrecuperáveis para a saúde? 3) Por que consomem drogas? 4) Por que não praticam exercícios físicos? Essa lista de perguntas é interminável, mas acho que podemos nos concentrar na questão número 2. O consumo de tabaco tem diminuído $^{12}$ desde que a tributação imposta ao produto aumentou consideravelmente, avisos de alerta foram introduzidos aos produtos e estabelecimentos públicos proibiram o fumo em suas dependências. Esse tipo de solução não é aplicável ao contexto da EF, pois não podemos propor um aumento dos juros (que já são altíssimos), proibição de consumo (já existem restrições de crédito para inadimplentes) etc. Contudo, o aviso de que o produto faz mal é até interessante de ser adotado nos contratos de empréstimo, cartão de crédito e cheque especial; mas esse não é o ponto.

Entendemos que o foco está na ideia, na insistência, no aprofundamento da reflexão sobre o problema, na forma como deve ser tratada uma pessoa com problema de compulsão ao consumo, em como deve ser revelada a realidade das famílias destruídas pelo superendividamento, algo parecido com as fotografias chocantes mostradas nos maços de cigarros. É bom ressaltar que a EC nos faz refletir sobre os comportamentos erráticos e discute as suas causas, mas não propõe de forma objetiva como seria possível mudar a realidade desses comportamentos.

Se estamos falando de educação, de trabalhar a EF no âmbito das escolas, temos de aceitar que não é suficiente o professor falar, expor, mostrar e explicar. Não é

\footnotetext{
${ }^{12} \mathrm{https}$ //www.terra.com.br/vida-e-estilo/saude/consumo-de-drogas-alcool-e-cigarro-cai-entrejovens,be7a92205ad67410VgnVCM4000009bcceb0aRCRD.html https://veja.abril.com.br/blog/letra-de-medico/o-tabagismo-no-mundo-e-no-brasil/ http://www.blog.saude.gov.br/index.php/35568-numero-de-fumantes-no-brasil-cai-30-7-nos-ultimosnove-anos
} 
DOI: http://dx.doi.org/10.33238/ReBECEM.2019.v.3.n.2.22614

suficiente a BNCC aconselhar, indicar, propor a inserção da EF na escola básica. Não é suficiente a escola incentivar e cobrar os professores para fazerem um tratamento interdisciplinar da EF. Tudo isso é necessário, mas não parece ser o bastante. Precisamos pensar em incentivar o aluno refletir, a falar, a expor a sua realidade, a entender o porquê de as pessoas terem comportamentos erráticos e ilógicos em relação às suas finanças. Uma atividade pedagógica que pode ser útil é dar aos alunos fragmentos de textos de Bauman para que leiam e façam apresentações, discussões e debates, para que pratiquem um discurso voltado à conscientização sobre os problemas financeiros.

Precisamos trabalhar para fazer os estudantes entenderem que os recursos são escassos, que as famílias tem de viver dentro de sua restrição orçamentária, que consumir representa um tradeoff e que as pessoas que se endividam estão valorando errado os produtos, estão forçando uma curva de indiferença mais alta, mas a consequência de viver em uma propensão marginal a consumir maior que 1 é drástica!

As pessoas não devem pagar qualquer preço para entrar no jogo do consumo, pois, como vimos, o consumismo aposta na irracionalidade. O sistema (a sociedade de consumo) vai fazer vítimas, vai incentivar o pagamento de uma dívida com outra dívida. Os estudantes precisam perceber que a vida a crédito é como uma droga, como disse Bauman.

Entendemos que esse tema merece maior aprofundamento em estudos posteriores, principalmente no que se refere à inserção da vertente comportamental na escola básica, buscando estratégias pedagógicas voltadas para isso. A EC também precisa ser melhor investigada em seus contornos relacionados ao consumismo e ao endividamento. A escola e a academia devem fazer a sua parte para não deixar os cidadãos abandonados à sua própria sorte, senão corremos o risco de estar apenas enxugando gelo com a ENEF.

\section{Referências}

ARIELY, D. Economia comportamental: um exercício de desenho e humildade. In: ÁVILA, F.; BIANCHI, A. M. (org.). Guia de economia comportamental e experimental. 1. ed. São Paulo: EconomiaComportamental.org, 2015. p. 19-24.

ÁVILA, F.; BIANCHI, A. M. Guia de economia comportamental e experimental. 1. ed. São Paulo: EconomiaComportamental.org, 2015.

ÁVILA, F.; INCHAUSTI, G. Economia comportamental aplicada às finanças pessoais. CFP Professional Magazine, São Paulo, ed. 11, p. 20-28, 2011. Disponível em: http://www.economiacomportamental.org/wpcontent/uploads/2017/07/CFPMag11_EconomiaComportamental.pdf. Acesso em: 08 jun.2019. 
DOI: http://dx.doi.org/10.33238/ReBECEM.2019.v.3.n.2.22614

BAUMAN, Z. Modernidade líquida. 1. ed. Rio de Janeiro: Zahar, 2001.

BAUMAN, Z. Vida para o consumo: a transformação das pessoas em mercadoria. 1. ed. Rio de Janeiro: Zahar, 2008.

BAUMAN, Z. Vida a crédito: conversas com Citlali Rovirosa-Madrazo. 1. ed. Rio de Janeiro: Zahar, 2010.

BRASIL. Ministério da Educação. Base Nacional Comum Curricular: educação é a base. Brasília: MEC, 2018. Disponível em: http://basenacionalcomum.mec.gov.br/. Acesso em 05 jun. 2019.

CAMPOS, C. R.; COUTINHO, C. Q. S. O juro real no contexto da educação financeira crítica. Tangram - Revista de Educação Matemática, Dourados, v. 2, n. 2, ano II, p. 67-86, 2019.

CAMPOS, C. R.; HESS, A.; SENA, R. M. Teaching financial mathematics through a critical approach in a university environment. In: JURDAK, M.; VITHAL, R. (ed.). Sociopolitical dimensions of mathematics education: from the margin to mainstream. 1. ed. Cham, Switzerland: Springer International, 2018. p. 113-132.

COUTINHO, C. Q. S.; CAMPOS, C. R. Perspectivas em didática e educação estatística e financeira: reflexões sobre convergências entre letramento matemático, matemacia, letramento estatístico e letramento financeiro. In: OLIVEIRA, G. P. (org.). Educação matemática: epistemologia, didática e tecnologia. 1. ed. Campinas: Livraria da Física, 2018. p. 143-180

FRANCESCHINI, A. C. T.; HUNZIKER, M. H. L. Conciliando economia e análise do comportamento no estudo da relação entre renda e comportamento de consumir. Revista Brasileira de Análise do Comportamento, Belém, v. 7, n. 1, p. 29-44, 2011.

KEYNES, J. M. A Teoria Geral do Emprego, do Juro e da Moeda. 2. ed. São Paulo: Nova Cultural, 1985.

MANKIW, N. Gr. Princípios de Microeconomia. Tradução de Maria José Cyhlar Monteiro. 1. ed. São Paulo: Cengage Learning, 2010.

PEREIRA, O. L. F. et al. Pobreza, desenvolvimento e comportamento humano: análise e conceituação sob o enfoque da economia comportamental. Revista Economia e Desenvolvimento, Santa Maria, v. 30, n. 4, p. 1-12, 2018.

PINDYCK, R. S.; RUBINFELD, D. L. Microeconomia. 7. ed. São Paulo: Pearson, 2010.

Recebido em: 14 de junho de 2019.

Aceito em: 17 de agosto de 2019. 